\title{
The Delphic Proxeny Network
}

In this chapter, the Delphic proxeny network serves as a case-study in order to demonstrate a particular honour 'at work'. The chapter thereby bridges the discussion of the Delphic gift-giving system in Chapter 2 and that of the types and categories of honorands in Chapter 4, since it discusses a large group of recipients of Delphic proxenia. Although recent studies have produced impressive conclusions concerning the whole concept of Greek proxenia, Delphic proxenia in particular deserves further consideration for several reasons. ${ }^{1}$ Firstly, Delphi published over 700 proxeny records, which made it, together with Delos (239), Oropos (207) and Athens (151), by far the most prominent locations for publishing proxeny decrees. ${ }^{2}$ Mack, in his well-received study on proxenia, has thoroughly examined its meaning as well as the tasks and duties which proxenoi were expected to perform, so there is no need for another explanation of proxenia. ${ }^{3}$ What concerns me here is rather the unprecedented scale at which proxenia was granted in post-classical Delphi in comparison with other poleis, as well as the range of the Delphic proxeny network. Secondly, in contrast to hundreds of Delphic proxenoi, only twenty Delphic citizens became proxenoi of other communities. Why is this lack of proportion so significant? Why did the inhabitants of Delphi not perform the duties of proxenoi very often? Thirdly and lastly, proxenia was still being granted in Delphi during the imperial period, whilst in other parts of Greece it had generally lost its significance after the consolidation of the administrative system and the implantation of Roman policy in the East under Augustus. ${ }^{4}$ This allows Delphic proxenia to be examined within a much broader historical context.

Mack provides us with a brief definition of proxenia in the preface to his study: '[p] roxenia was an honorific status granted to foreign benefactors which permitted poleis to establish permanent networks of these individuals (proxenoi), connecting them as communities to large numbers of other poleis and facilitating interactions between the citizens of different cities'. Mack also states later that proxenia: " $[\mathrm{w}]$ as based on a shared understanding of the proxenos as

1 Walbank 1978; Henry 1983; Marek 1984; Gauthier 1985; Herman 1987; Lambert 2012; Mack 2015 .

2 Mack 2015, 14 fn. 32; Constantakopoulou 2017, 117.

3 Mack 2015.

4 Mack 2015, 244-248; Zoumbaki 2017, 252 fn. 13.

(C) DOMINIKA GRZESIK, 2021 | DOI:10.1163/9789004502499_005

This is an open access chapter distributed under the terms of the CC BY-NC 4.o license.ka Grzesik - 9789004502499 
the official friend of another city who performed certain sorts of intermediary function within the context of his own political community.' ${ }^{5}$ The entire honorific habit which proxenia entailed allowed a polis to create links with the outside world and for centuries it was the best available instrument to enable this. The use of network theory as a methodological tool allows proxenia to be viewed through different lenses from before. Network terms present proxenia not only as one of the many gifts granted by Greek city-states to foreign benefactors, but also as a type of 'language' that established links between 1000 poleis, who were able to communicate and establish relationships (of different types, strengths and directions) with one another.

During the last few decades, scholars investigating ancient civilizations have increasingly turned to methodological approaches that originate outside the field of ancient history. One of these approaches, Social Network Analysis (SNA), considers the structural dynamics of networks in the ancient world and, as such, is of particular relevance to this study. In the social sciences, networks denote relationships between people or objects within and across physical, social, or temporal contexts. In particular, the SNA approach prioritises and highlights links over boundaries, connectivity over isolation, and interaction over separation - with all the expected benefits and biases. ${ }^{6}$ The use of SNA has yielded valuable data when applied to various subfields of ancient history, yet networks as a methodological concept have proven themselves particularly productive for studies regarding the ancient economy ${ }^{7}$ and archaeology. ${ }^{8}$ Over time, more and more scholars of ancient history have elected to scrutinise their research topics through the lens of sNA. This has resulted in a number of excellent contributions, which include Malkin's recent book on Greek colonization

5 Mack 2015, vii and 9o. The proxeny habit has attracted considerable attention in scholarship, see Marek 1984; Gauthier 1985, 131-149; Herman 1987; Habicht 2002, 13-3o. Athenian proxeny decrees have for decades been at the centre of debate concerning the epigraphic tradition: Walbank 1978; Henry 1983; Lambert 2012, 93-137; Meyer 2013, 454-505. For proxenia outside Athens, see e.g. Fossey 1996, 158-167 (Aetolia); Knoepfler 2001 (Eretria); Zelnick-Abramovitz 2004, 93-106 (western Greece); Tzifopoulos 2010, 355-368 (Crete); Wilding 2015, 55-82 (Oropos).

6 Taylor and Vlassopoulos 2015a, 10. Milgram 1967; Watts and Strogatz 1998; Degenne and Forsé 1999. For the historiography of network analysis in sociology, history and archaeology, see Knox, Savage and Harvey 2006; Brughmans 2010 and 2013; Lemercier 2012. Further references: Malkin 2011, 26-27.

7 Foxhall 2007; Morris, Saller and Scheidel 2007; Harris, Lewis and Woolmer 2016.

8 E.g. Graham 2006; Knapp 2008; Brughmans and Poblome 2016. For more references, see Constantakopoulou 2017, $10 \mathrm{fn}$. 3 o. 
recast in network terms, ${ }^{9}$ Taylor and Vlassopoulos' studies on social networks in classical Athens, ${ }^{10}$ several works on social networks in religious, festival and athletic contexts, ${ }^{11}$ and Mack's article which applies sNA methodology to Athenian grants of citizenship. ${ }^{12}$ Since, as mentioned above, an sNA approach also fosters certain cognitive biases, I decided - following Constantakopoulou's example - to employ only those aspects of sNA that overlap closely with my research questions and are able to yield comprehensive results. ${ }^{13}$ More specifically, I will use the SNA concepts of social integration, human agency and weak/strong ties within networks to look for regularities, continuities, and entanglements within the Delphic proxeny network.

According to Mack, there are 735 preserved proxeny decrees from Delphi, 239 from Delos, 207 from Oropos and only 151 from Athens. ${ }^{14}$ Even more striking results emerge from comparison with other poleis. In $70 \%$ of cities the granting of proxenia is attested in less than five documents, and in $6 \circ \%$ less than three proxeny decrees were published. ${ }^{15}$ Therefore, when combined, Delphi, Delos, Oropos and Athens provide more than half of all published proxeny records. ${ }^{16}$ Why is this disproportion so significant? Why does Delphi leave other cities so far behind?

Malkin 2011. The literature on this matter is voluminous: see Malkin, Constantakopoulou and Panagopoulou 2009; Cline 2012, 59-70; Taylor and Vlassopoulos 2015 b and articles published within this volume. Constantakopoulou 2017 and 2019, 83-98. For the network in Byzantine Egypt, see Ruffini 2004, 241-257; for the road network in the Peloponnese, see Shipley 2018, 281. For a general overview on the current state of network analysis in the field of ancient history, see Nitschke and Rollinger 2015; Verschueren 2016; Haake 2019, 308-309.

10 Taylor 2015, 35-53; Vlassopoulos 2015, 101-127.

11 Collar 2013; van Nijf and Williamson 2016, 43-73; Mann 2018 293-312; Rutherford 2019, 165-181; Papazarkadas 2019, 205-221; Steinhauer 2019, 223-237.

12 Mack 2015 and 2019, 61-82.

13 Constantakopoulou 2017, 10. For human agency networks, see Latour 2005.

14 Mack 2015, 14 fn. $3^{2}$ and 235 fn. 4. Mack in his study includes only those Delian proxeny decrees where proxenia is securely attested. Marek $(1984,247)$ and Habicht $(2002,15)$ mention between 467 and 500 Delian proxeny decrees, but many of these texts are highly fragmentary or uncertain.

15 Mack 2015, 16.

16 The League of the Aetolians also created an impressive network with over 239 proxenoi. However, in contrast to Delphi, Delos, Oropos and Athens, the Aetolians inscribed their proxenoi in the form of eight stelai bearing twenty-four chronological lists of those appointed between the third and the early second century все. Therefore, the Aetolian proxeny network is of no use with regard to explaining the phenomenally high number of Delphic proxeny decrees. See: $I G{\mathrm{IX}, 1^{2}}_{1}$ 1, 13, 17, 21, 24, 25, 29, 30 and 31. Cf. Fossey 1996, 158-167; Mack 2015, 288-291. 
The remarkable number of inscriptions from Delphi that have been preserved, a staggering 3727 texts, may provide the answer. ${ }^{17}$ It is universally accepted that in many poleis inscriptions were inscribed only occasionally and there was no reason to regularly carve grants of proxenia, examples of which appear only in a select number of cases. ${ }^{18}$ The process of engraving texts of inscription was considered as additional honour and it is believed that only a small proportion of the decrees which were voted on were committed to stone. ${ }^{19}$ Therefore, one might assume that, since there are much fewer inscriptions from other cities than from Delphi, the number of proxeny records would be proportionately smaller. The case of Priene, however, contradicts this theory. McCabe collected 1273 inscriptions from Priene in total, but only five of them have been catalogued by Mack as proxeny decrees. ${ }^{20}$ Also, the ratio of proxeny records within the rich Athenian epigraphic habit is much smaller than in Delphi. So what was so exceptional about Delphic proxenia that it was both granted and inscribed so often in comparison with other poleis?

The case of Delos might help to tackle some aspects of this puzzle. Constantakopoulou claims that independent Delos was not only a location of the famous sanctuary of Apollo, which attracted numerous pilgrims and worshippers, but also due to its central position in the Cyclades it served as a regional centre for commerce and economic transactions. It was additionally a navigational centre with an impressive network of participants. Delos thus provided an excellent showground with a large audience and became, along with Delphi and Oropos, one of the most prominent locations for publishing proxeny decrees in Greece. ${ }^{21}$

The Panhellenic shrine at Delphi (along with its festivals) provided an even greater multi-ethnic crowd and this, together with the associated publicity, made Delphi the ideal spot to flaunt one's status. Therefore, it seems likely that, when a proxeny decree was issued in Delphi, it had a much better chance to be publicised on one of the Delphic walls than outside of Delphi. Visitors would see that becoming Delphic proxenoi (and therefore Delphic benefactors, as all proxenoi were also euergetai), paid off, as in Delphi they made their grants

\footnotetext{
17 Chapter 1.

18 Mack 2015, 14.

19 For a lengthy discussion on this matter, see Wilhelm 1909, 271-275; Klaffenbach 1966; Hansen 1984, 123-155; Walbank 1988, 57-59; Tracy 1990, 235-236; Rhodes and Lewis 1997; Davies 2003, 328. Pace them, Osborne $\left(2012,33^{-52}\right)$. For engraved decrees as additional honours, see Domingo Gygax 2016, 23 .

$20 \quad$ McCabe 1987; Mack 2015, 15-16.

21 Constantakopoulou 2017, 117-119.
} 
visible. ${ }^{22}$ This increased the number of wealthy benefactors who willingly became proxenoi of Delphi. Proxenia inscribed within the Delphic temenos served as a proleptic honour, whose task was to encourage other benefactors to work towards gaining the honorific title of Delphic proxenos through their benefactions. The system of inscribing honours encouraged people to spend large sums of their private fortunes on the city. It also fuelled the race for honours as proxenia came to function as a prize in a euergetic contest. The bulk of Delphic proxeny decrees come from the third century вСЕ, a time when Delphi still acted as an important international centre. By virtue of his proxenia, the proxenos acquired prestige which elevated his position and importance within the polis he was associated with. ${ }^{23}$ As Kyriakidis notes, the Delphic proxenia was a sort of 'le "carnet d'adresse" du dieu'.24 In this way the possession of Delphic proxenia was prestigious and allowed one to stand out among one's fellow citizens. Proxenia fuelled a rivalry between urban elites to gain higher honours outside their own city. Moreover, proxenia was often granted together with other privileges that might have been tempting for economic reasons. This explanation clarifies the answer to the question posed in Chapter 1: Why did the small city of Delphi produce such a large number of honorific texts? The Delphians knew that the role of decrees was to communicate honours and relationships, as well as that the publication of honorific decree-texts would prompt the cosmopolitan crowd to make further benefactions. Proxeny decrees were not only published in visible places so they could be seen by large numbers of visitors; their placement was also intended to make an impact on the international audience and stimulate the race for honours. This was nowhere demonstrated more clearly than in Delphi, Delos and Athens.

Most modern scholars who deal with the Oropian or Boeotian epigraphic habit make no reference to the reasons behind the great number of proxeny decrees from Oropos. Fossey loosely connects it with the international importance of the religious centre at the Amphiaraion, but this issue needs further study, since there were more important sanctuaries across Greece that did not produce as many proxeny decrees as Oropos. ${ }^{25}$ The Athenian festivals and temples attracted more visitors annually than the sanctuary of Amphiaraos, yet there is less epigraphic evidence of proxeny practice from Athens than from Oropos. Athens produced the highest number of decrees known from the ancient world. The honorific culture at Athens developed together with the

\footnotetext{
22 For proxenoi as euergetai, see Mack 2015, 40.

23 Mack 2015, 113-114.

24 Kyriakidis 2019, 105.

25 Fossey 2014, 9. See also Wilding 2015, 55-81; Papazarkadas 2016, 121-146.
} 
spread of democracy and Athenian imperialism, and it seems that, at the centre of the empire, it was not only honorific decrees that were inscribed, since the Athenians often recorded democratic decisions concerning the functioning of the polis and the empire on stone. ${ }^{26}$ Moreover, local benefactors formed an important group of recipients of Athenian honours who were not naturally granted proxenia, while Delphic decrees provide scant information concerning the topic of civic euergetism. ${ }^{27}$ Also, as Lambert rightly notes, the greatest privilege that Athens bestowed upon foreigners was Athenian citizenship, not proxenia. ${ }^{28}$ In contrast to Athens, Delphi did not depend on local euergetai, but instead relied on foreign benefactors, on whom the entire honorific culture of the Hellenistic period was focused.

Before proceeding, it must be stressed once again that, contrary to widespread belief, not every decision of the boule and demos was automatically carved in stone, but numerous factors impacted the decisions behind what should be immortalised in the form of a stone decree and in what quantity. The economic factor must have been especially relevant as inscribing texts always came at a price. ${ }^{29}$ On the whole, different poleis engraved different inscriptions and in different quantities.

This diversity raises another possibility: can we assume that, in contrast to other Greeks, the Delphians inscribed perhaps not all but at least the majority of their honorific decrees, which ultimately resulted in such a high number of stone proxeny documents? Osborne, in his recent study, argues that the notion of selecting honorific decrees destined for publication on stelai in Athens is incompatible with the idea that everyone was encouraged to contemplate the awards to benefactors in the sure knowledge that they will be similarly recompensed if they perform benefactions themselves. This process would introduce 'a second class set of honorands' who would be mentioned only in the assembly and subsequently recorded exclusively in the archive. ${ }^{30} \mathrm{He}$ concludes that: [ $t$ ] he perceptibly official status of inscribed stelai of public decrees implies that all must have been inscribed and that there is no conclusive evidence to indicate that such a practice would have been beyond the availability of funding and of letter-cutters.' ${ }^{31}$ One may not agree with Osborne's argumentation

26 Hedrick 1999, 387-439; Lambert 2012; Meyer 2013, 74-93. Between 399-338 вС , however, the number of honorific texts began to surpass the number of non-honorific decrees, see Osborne 2012, 53 .

27 Lambert 2012, 3-47; Osborne 2012, 54.

28 Lambert 2012, 93 .

29 Constantakopoulou 2017, 172.

30 Osborne 2012, 48-52.

31 Osborne 2012, $5^{2}$. 
concerning Athens, but his study offers a new way to view the Delphic publishing habit. First of all, through the use of building walls as the prime medium for inscriptions, Delphi had enough space within its small temenos to house hundreds of honorific texts. ${ }^{32}$ Secondly, abbreviated decrees and the use of building surfaces reduced the costs of inscribing decrees to a minimum. ${ }^{33}$ In view of this, it seems quite plausible, that the citizens of Delphi were able to turn most voted decrees into stone. This would explain the extraordinary number of preserved proxeny decrees from Delphi. The publication habit was more developed in Delphi than in other poleis. It provided a catalyst that stimulated foreign benefactors to compete in the race for honours, since it was better to be a recipient of a published decree in a Panhellenic sanctuary than to have your award hidden somewhere in the local archive. The publishing habit was an important and well-developed component of the Delphic honorific culture that distinguished Delphi from other poleis, even from those with a rich honorific habit, which explains Delphi's great number of preserved honorary texts and the large number of proxeny records.

\subsection{The Delphic Proxenia and Regional Interactions}

The presentation of the Delphic network of proxenoi in map-form is a fruitful way to visually represent the directions to which Delphi looked during particular periods. Did Delphi look westward, eastward or northward, and when? As well as indicating which direction Delphi turned, the map also enables the geographical scope of the proxeny network during the periods in question to be ascertained, so that we can answer the question, was it more regional or more global (Maps 1-2)?

The material that presents the range of the Delphic proxenia is shown in the form of five maps (Maps 3-7). The texts are arranged by 100-year period, with the one exception being 'the imperial period' which incorporates the first and second centuries CE. This is due to the fact that from the Augustan period onwards Delphic proxenia was in decline, its character had changed and any significant tendencies would not be readily apparent if the era was split into 100-year periods. ${ }^{34}$ Moreover, many abbreviated decrees from this period are simply dated as imperial texts, with no specific century being listed.

$32 \quad$ Chapter 6.

33 Chapter 5 .

34 See Chapter 2.1.2. 


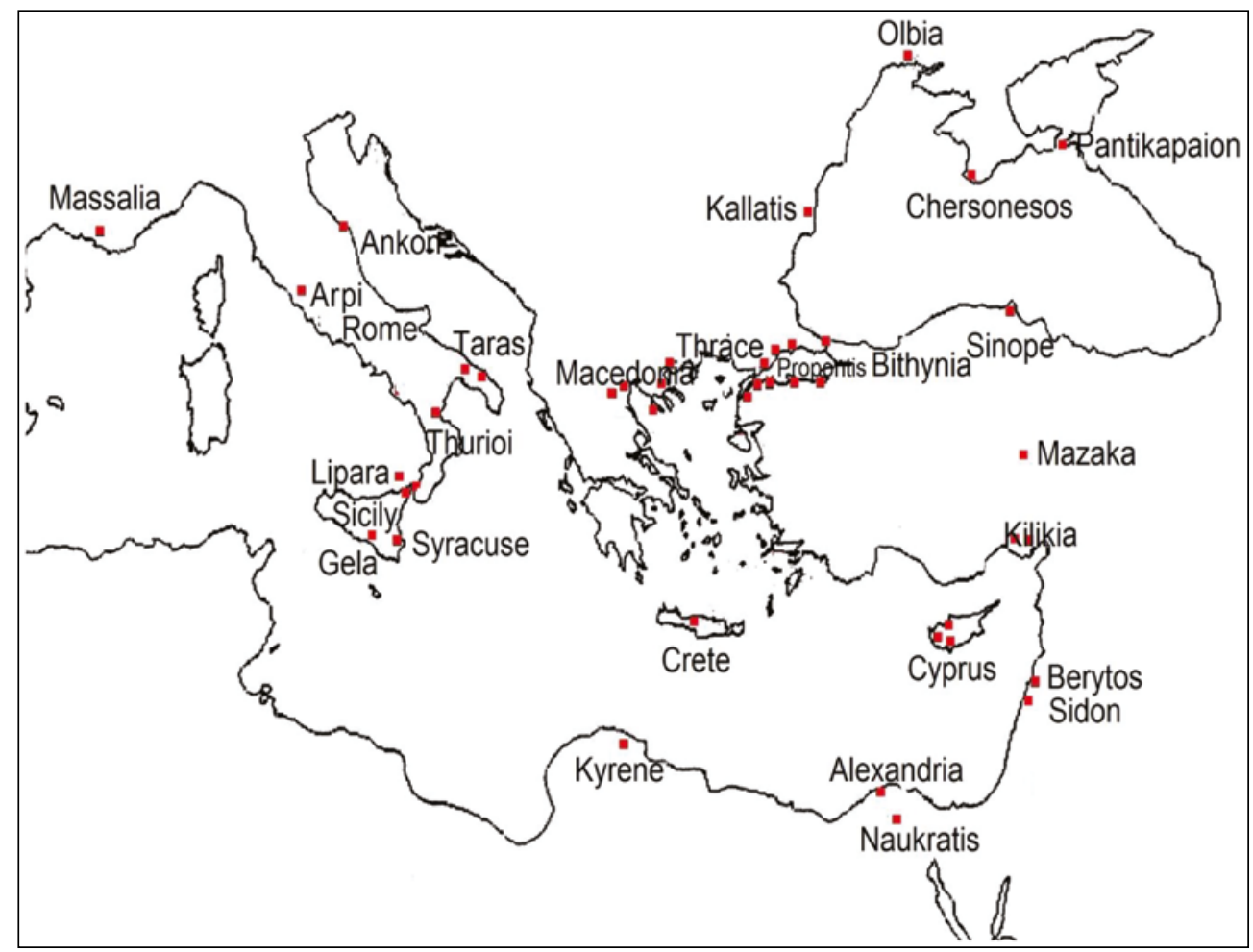

MAP 1 The places of origin of Delphic proxenoi from the most remote territories

There are 735 preserved proxeny records from Delphi; to appear on one of the maps, however, a proxeny decree needs to meet two conditions. The first is that the date of the inscription must be established at the least to a century (or as an imperial text); undated texts or those dated by the editors as 'Hellenistic' are not included. The second condition concerns the ethnicon of the proxenos. Those proxeny decrees in which the honorand's ethnicity appears as highly fragmentary, or is uncertain, lost or not mentioned, have been excluded. Only datable texts and decrees where the proxenos' origin is securely preserved are represented. This ethnic condition eliminated a bulk of abbreviated decrees since, unlike full pattern decrees which always mention the recipient twice, abbreviated documents only list them once. More often than not, this has resulted in the ethnicon being lost. ${ }^{35}$ Another difficulty is the fact that several poleis went by the same name and it is not always certain which city the proxenos comes from. For instance, there are cities that share the name 


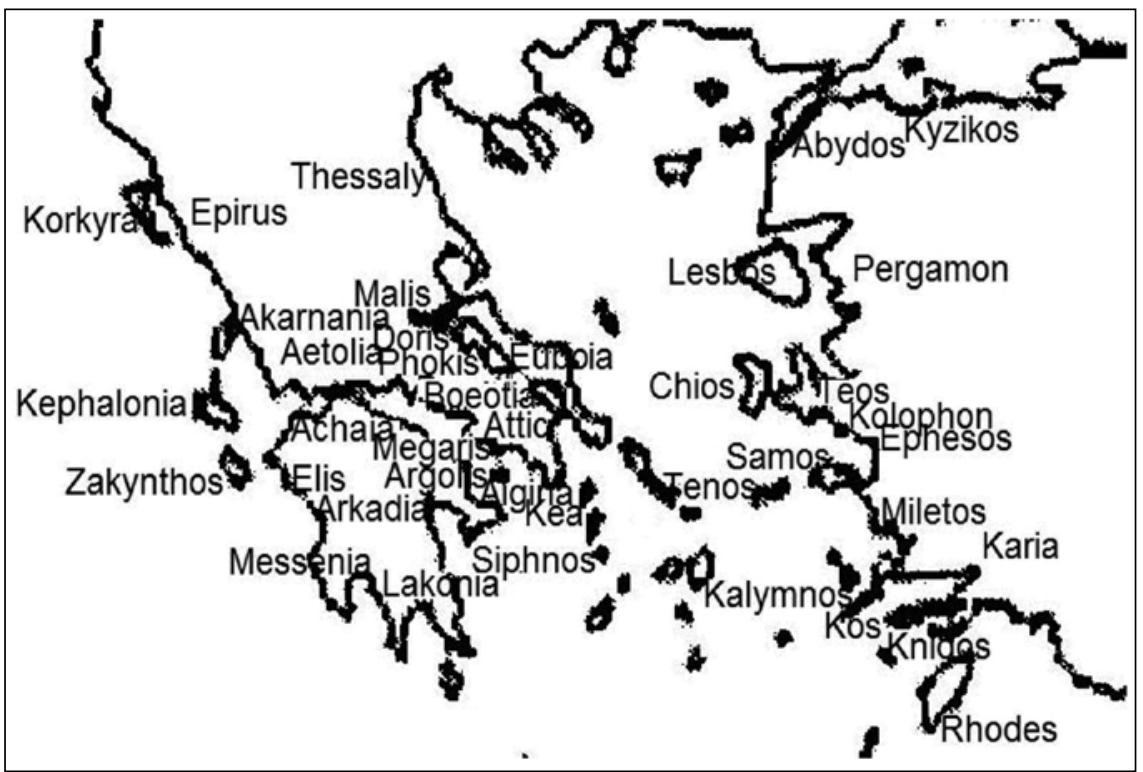

MAP 2 The places of origin of Delphic proxenoi from central Greece, the Aegean islands and the west coast of Asia Minor

Herakleia located in the Pontus area, Macedonia, Asia Minor, Sicily and southern Italy. ${ }^{36}$ The last minor methodological problem concerns unidentified poleis, such as Parasopioi, which appear in two Delphic proxeny decrees. ${ }^{37} \mathrm{It}$ is known that Parasopioi was located somewhere in Oita, but its exact location remains a mystery. ${ }^{38}$ After applying these rules, the dataset offers 553 items. This figure is smaller than the total number of proxeny decrees from Delphi, but the data consists of secure material and still provides a representative sample of inscribed grants.

The purpose of the maps is to illustrate the range of the Delphic proxeny network and not the total number of proxenoi; therefore, proxenoi who originate from the same city are represented by a single dot on the map.

To begin with, let us look at the map which shows the Delphic proxeny network in the fourth century BCE (Map 3). This map shows a concentration of the Delphic proxenoi in central Greece, where the citizens of Boeotia and

$3^{6} \quad$ See also Fossey 2014, 12.

$37 \quad F d D 1.118$ and $F d D 2.183$.

38 Decourt, Nielsen and Helly 2004, 709 (no. 426). 


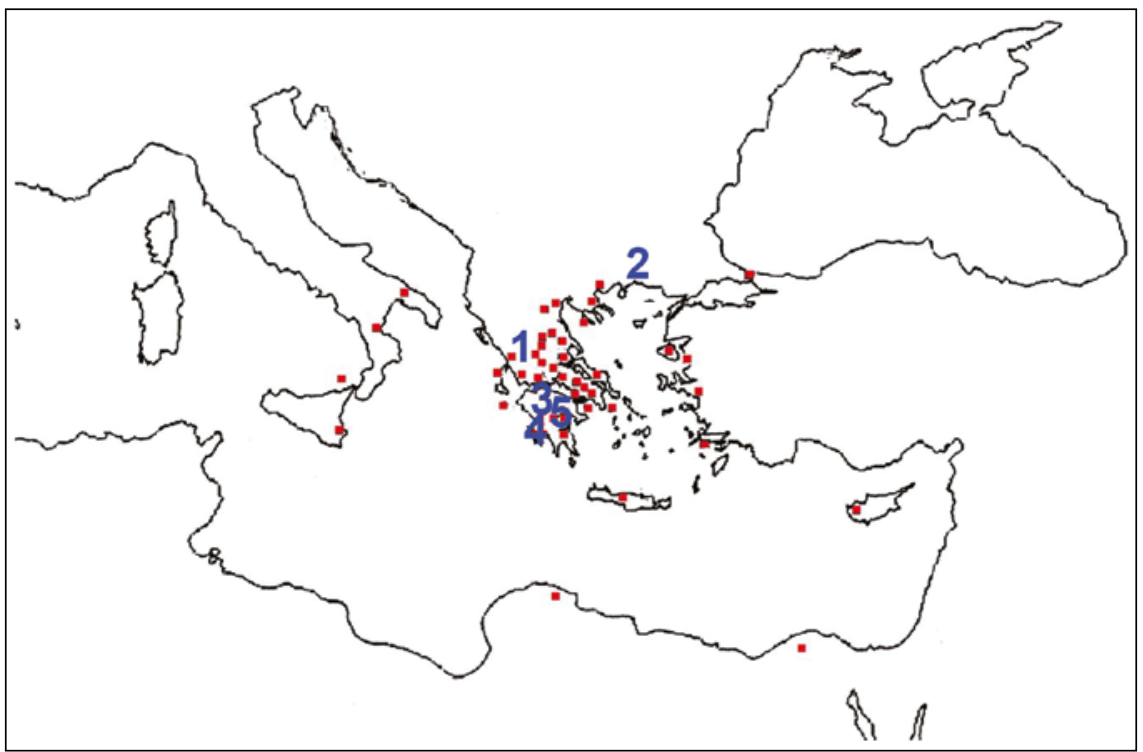

MAP 3 The fourth century вСE network of Delphic proxenia

Note: Nos. on the map: 1 - Aetolia; 2 - Thrace; 3 - Achaia; 4 - Messenia; 5 - Arkadia. The numbers on the map(s) represent those regions with large numbers of proxeno $i$ that were inscribed without the name of a particular polis.

Thessaly prevail among the recipients of Delphic proxenia. ${ }^{39}$ The Boeotians and Thessalians were the dominant powers both in central Greece and in the Amphictyony at that time, thus their appearance in large numbers as Delphic proxenoi should not be surprising. ${ }^{40}$ The trend of honouring major figures in the Greek world was notable at Delphi throughout antiquity. The citizens of Boeotia and Thessaly were replaced as the most common recipients of Delphic proxenia by the Macedonians after 346 вСE, when Philip II defeated the Phokians in the Third Sacred War. As a reward, Philip replaced the Phokians in the Amphictyonic council and, along with many other Macedonians, was granted proxenia together with priority to consult the oracle (promanteia), which resulted in the entire Delphic epigraphic habit gaining a strong Macedonian flavour in the second half of the fourth century вСЕ. ${ }^{41}$

39 Proxenoi from Boeotia: $F d D$ 1.96, $F d D$ 1.365, $F d D$ 1.416, $F d D$ 3.92, $F d D$ 3.95, $F d D$ 3.96, $F d D$ 3.102; SGDI 2674, SGDI 2747. Proxenoi from Thessaly: FdD 1.164, FdD 1.401, FdD 4.378, FdD 4.394; SEG 18.179, SEG 22.462.

40 Lefèvre 1998; Sánchez 2001, 518; Kyriakidis 2019, 100-101.

$41 S y l l^{3} 221 \mathrm{~B}$ - honorific decree for Philip II. Other Macedonians attested as Delphic proxenoi in the fourth century вСE are: $F d D$ 4.391, FdD 4.405; SGDI 2759, SGDI 276o; Syll ${ }^{3} 268 \mathrm{H}$; 
The citizens of Athens and the Peloponnese had close links with Delphi throughout the entirety of the Hellenistic and Roman periods and so Delphic proxeno $i$ which originate from these regions are widely attested on all maps (3-7). From this we can conclude that, using SNA terms, Delphi had long-term ties with Athens and Peloponnese. The remaining ethnics are widely distributed and spanned the territories of Magna Graecia - Syracuse, ${ }^{42}$ Taras, ${ }^{43}$ Lipara, ${ }^{44}$ Thurioi (which has been included even though the ethnic in this case is a restoration $)^{45}$ - Kyrene in Libya, ${ }^{46}$ Naukratis in Egypt ${ }^{47}$ Cyprus ${ }^{48}$ and Byzantion. ${ }^{49}$

The fourth century BCE network of Delphic proxenoi is broad if we take into account the fact that the honorific culture was in its infancy and that the map covers only $c$. 60 years, not 100 (or more) as in the following periods. ${ }^{50}$ At the same time, Delphi's contacts were limited to Greek cities and their colonies located in the Mediterranean area, unlike the Hellenistic and Roman periods when Delphic proxenoi originating from distant regions beyond the Mediterranean Sea appear.

The third century вСЕ was the golden age of the Delphic honorific habit and Greek peer-polity integration. ${ }^{51}$ The political culture of Greek poleis depended upon forming links with other communities and proxenia was a vital medium which enabled cities to negotiate and articulate their evolving identity in the Greek world. ${ }^{52}$ Proxenia helped to negotiate a polis' position within a wider world of interactions and there was no better place to articulate one's status than at Delphi. The 'need to belong' to the Greek world in the third and second centuries BCE is particularly visible in the case of Delphic proxenoi which

SEG 45.473. See Arnush 2000, 293-307; Miller 200o, 263-281; Sánchez 2001, 220-268; Grzesik 2019, 207-208.

$42 \quad F d D$ 1.437.

$43 \quad F d D 1.135$.

$44 \quad F d D 4.401$.

$45 \quad F d D 4.388$.

46 Collective proxenia to all citizens of Kyrene (Kyrene is a reconstruction), Bousquet 1952, 69 .

$47 \quad F d D$ 1.419.

$48 \quad F d D 4.396$.

49 SEG 18.180.

50 One of the earliest Delphic proxeny decrees is dated to 36 о- 358 вСе (Syll 189 ).

$5^{1} \quad$ Chapter 1. See also Jones 1964, 4; Ma 2003, 9-39; Magnetto 2018, 85-108.

$5^{2} \quad$ Wilding 2015,55 . 


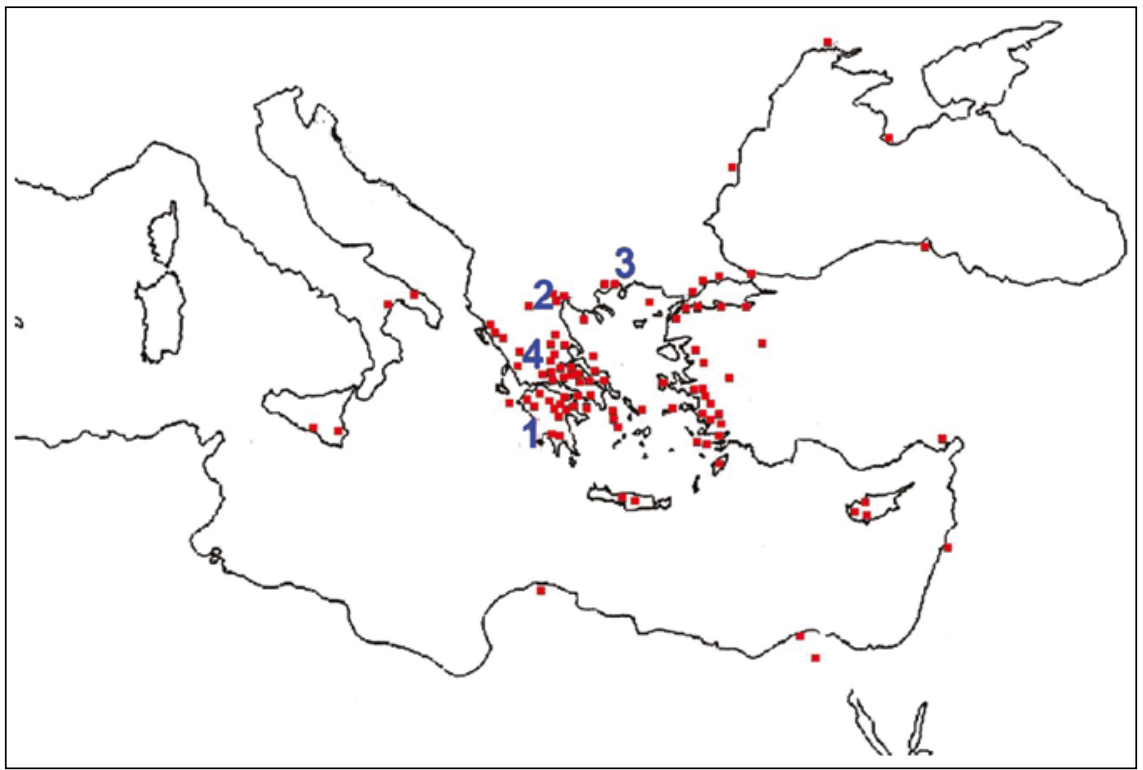

MAP 4 The third century вCE network of Delphic proxenia

Note: 1 - Messenia; 2 - Macedonia; 3 - Thrace; 4 - Aetolia.

originate from the distant territories of Epirus, ${ }^{53} \mathrm{Kilikia}^{54}$ and Phrygia, ${ }^{55}$ places that were not necessarily linked with the Greeks during the classical period. ${ }^{56}$ It would not be an exaggeration to say that the Delphic proxenia facilitated the Hellenisation of these regions, as it enrolled their inhabitants into the Greek world of honours. The northern regions of Greece were readily disregarded by the Greeks from the south. As Daubner puts it, there were no peace or isopoliteia treaties, no symmachia pacts, no involvements in international arbitration, and no participation in the exchange of foreign judges, all of which are institutions said to be typical of Hellenistic poleis. Grants of proxenia and sending theorodokoi to Macedonia and Epirus seem to be the exclusive tools used by the Greeks to integrate the citizens of the periphery with the Greek core. ${ }^{57}$ The fact that no other citizen of the Epirote tribes or Mallos in Kilikia was granted proxenia outside of Delphi reinforces the argument that Delphic

53 Delphic proxenoi from Thesprotia ( $F d D$ 2.83), Chaonia ( $F d D 4.409$ II 7$)$ and Phoinike (SGDI 2589) in Epirus.

54 Delphic proxenos from Mallos in Kilikia $(F d D$ 1.84).

55 Delphic proxenos from Phrygia (SGDI 2598).

56 Thukydides describes the Epirotes as barbarians (Th. 1.8). See also Davies 2002, 234-258; Daubner 2018, 132-135.

57 Daubner 2018, 133 and 136-149. On isopoliteia in Hellenistic times, see Saba 2020. 
proxenia was an exceptional honour that connected the peripheral areas with the centre of the Greek world. ${ }^{58}$

From the fourth century BCE onwards, it was typical at Delphi to honour citizens of the dominant powers in central Greece with proxenia. First among the recipients of Delphic proxenia were the Boeotians and Thessalians, then the Macedonians. After 279 BCE, the League of the Aetolians took over control of the Delphic territory and the Amphictyonic council, and many Aetolians received the honorific title of Delphic proxenoi. ${ }^{59}$ At least three citizens of Delphi also performed as proxenoi of the League of the Aetolians, establishing among the Delphians and Aetolians a bilateral relationship (Appendix 2, nos. 1-3). The trend of honouring the main forces in central Greece allowed Delphi to secure sympathetic treatment during times of upheaval, while also facilitating good relations with the dominant powers in Greece.

The rest of the Delphic network of proxenoi in the third century вСЕ can be analysed via employing Mack's model, which identifies three types of regional interaction between poleis: (a) a narrow network in which a polis created links with the neighbouring territories; (b) a second type with a well-defined local network, as well as some strong engagements with more distant regions; and (c) a network in which a polis had a well-defined region of primary interaction, but, instead of having a secondary area, created links with a much wider geographic range of poleis. ${ }^{60}$ Following Wilding's approach, it is possible to link Delphi's third century вСЕ proxeny network with all three types of interaction, since it fits all three models in the following way: (a) central Greece, ${ }^{61}$ Attica ${ }^{62}$ and the Peloponnese ${ }^{63}$ formed the narrow network; (b) Macedonia, ${ }^{64}$ the

$5^{8}$ There is an Oropean proxeny decree regarding Daippos, son of Nikanor, the ethnicon of which describes him as a citizen of Epirus ('H $\pi \varepsilon ı \omega \dot{\omega} \tau \eta \nu)$, and not a citizen of a particular tribe (I.Oropos 136, c. 240-180 ВСE).

59 Sifakis 1967, 65. Cf. Flacelière 1937, 367; Champion 1995, 213-220. The Delphic proxenoi from Aetolia: FdD 1.142-150, FdD 3.198 and 199; SGDI 259o, SGDI 2595, SGDI 2596, SGDI 2666.

6o Mack 2015, 175-182.

61 E.g. Aetolia $(F d D$ 1.142-145); Thebes $(F d D$ 1.359-361, $F d D$ 3.82); Thespiai $(F d D$ 2.189, $F d D$ 3.81); Tanagra ( $F d D$ 3.79, $F d D$ 3.10o); Chaironeia ( $F d D$ 3.84); Plataia ( $F d D$ 3.116); Labadeia $\left(F d D_{3} .85\right)$; Lokris $(F d D$ 2.186); Larisa $(F d D$ 3.180).

62 Athens ( $F d D_{2.71}, F d D_{2.73}, F d D_{2.7} 6, F d D_{2.81}, F d D$ 2.198).

63 E.g. Arkadia $(F d D$ 1.12, $F d D$ 1.14, $F d D$ 1.19, $F d D$ 1.38); Elis ( $F d D$ 1.126, $F d D$ 3.191, $F d D$ 3.196); Lakonia ( $F d D$ 1.426, $F d D$ 4.403); Messenia ( $F d D$ 4.11, $F d D$ 4.14, $F d D$ 4.24); Achaia ( $F d D 4.412)$; Akarnania ( $F d D$ 3.338, FdD 1.123; SGDI 2659).

64 E.g. $F d D$ 1.108, $F d D$ 1.112, $F d D$ 2.177, $F d D$ 4.16 The citizens of Macedonia are often referred to simply as Macedonians, without any reference to the city to which they belonged. Perhaps those Macedonians whose origins were not fully detailed were royal courtiers or officials, see Fraser 2009, 119-142; Mack 2015, 55. 
Aegean islands ${ }^{65}$ and the west coast of Asia Minor ${ }^{66}$ represent the secondary regions; and (c) the Propontic areas, ${ }^{67}$ Hellespont, ${ }^{68}$ the Black Sea region, ${ }^{69}$ the south coast of Asia Minor, ${ }^{70}$ Syria, ${ }^{71}$ Egypt $^{72}$ and Magna Graecia ${ }^{73}$ constitute the widest network. ${ }^{74}$

In the third century BCE Delphi created links with Greek communities using other available tools besides the granting of proxenia. The most striking of this was the theoric network. As was noted in Chapter 2, a continuous record of theorodokia is attested at Delphi from the mid-fourth century вСE until the late first century вСе. ${ }^{75}$ The extended size of the Delphic theoric network is illustrated by a list of theorodokoi from the third century вСЕ which includes about 700 cities arranged in terms of routes. ${ }^{76}$ This perfectly mirrors the international scope of Delphi's interactions and the institutional infrastructure of both theorodokoi and proxenoi.

The Delphic proxeny network reached its quantitative apogee in the third century ВСЕ and was never so rich either before or after. Its spread reveals Delphi's wide geographical interactions not only among its neighbouring communities, but also with distant areas such as the Black Sea region, Asia Minor, the Levant and beyond. Becoming recipients of Delphic proxenia enabled the citizens of peripheral areas such as Epirus to align themselves with other inhabitants of the Greek world. Through their proxeny network, the Delphians renewed existing links with Athens, Thessaly, Boeotia and Macedonia, whilst also creating new links with Rhodes, Chios, Kallatis, Knidos, Alexandria and Soloi on Cyprus.

65 E.g. Rhodes ( $F d D$ 1.93, $F d D$ 1.97-1.99); Seriphnos ( $F d D$ 1.119); Kea $(F d D$ 1.124, $F d D$ 2.188); Kos ( $F d D$ 1.127); Crete $(F d D$ 1.439, $F d D$ 1.442); Zakynthos ( $F d D$ 2.185); Aigina ( $F d D$ 3.200, $F d D$ 4.149); Chios ( $F d D$ 3.216, $F d D$ 3.222); Tenos ( $F d D$ 4.225); Kalymnos (SGDI 2673).

66 E.g. Ephesos ( $F d D$ 1.54, $F d D 1.121$ and 122); Kolophon ( $F d D$ 2.75); Teos ( $F d D$ 2.134d); Miletos ( $F d D$ 4.177); Nasos ( $F d D$ 3.179); Karia ( $F d D$ 1.120, $F d D$ 1.133, $F d D$ 1.290, $F d D$ 1.327).

$67 \quad$ E.g. Kyzikos ( $F d D$ 1.429, $F d D$ 4.210); Lysimachia ( $F d D$ 1.430); Perinthos ( $F d D$ 3.207); Heraion (FdD 3.207).

$68 \quad$ E.g. Abydos $(F d D$ 1.131).

$69 \quad$ Kallatis ( $F d D$ 1.158); Chersonesos ( $F d D$ 3.207); Sinope ( $F d D$ 1.85); Olbia $(F d D$ 3.207).

$70 \quad$ Kilikia $(F d D$ 1.84).

71 Sidon $(F d D 1.435)$.

$72 \quad$ Naukratis $(F d D$ 1.114); Alexandria ( $F d D 4.427$ B v; $S G D I$ 2592, $S G D I 2650)$.

73 Tarent ( $F d D$ 1.109); Gela ( $F d D$ 1.125); Taras ( $F d D$ 1.443); Syracuse ( $F d D$ 3.157).

74 Wilding 2015, 59.

75 Chapter 2.1.2. See also Perlman 2000; Rutherford 2007, 23-27.

$76 \quad$ BCH 45.1921.1-85. See also Oulhen 1992; Rutherford 2007, 23-37; Malkin 2011, 20-21. For other lists of theorodokoi found at Delphi, see Daux 1949, 4-12 and Daux 1968, 629-630. For the Delphic theoric network, see Plassart 1921. 
Many factors impacted the global character of the Delphic proxeny network in the third century вСЕ. A few examples are the following: (1) the unprecedented integration of Greek poleis after the death of Alexander; (2) the 'need to belong' to the Greek world expressed by peripheral communities as well as by the Aetolians in the form of votive offerings or honorific texts located within Delphi's Panhellenic territory; (3) the Aetolian domination and creation of the Soteria festival, which attracted many visitors annually; (4) the peak of epigraphic production; and (5) the economic prosperity of the city. The mass production of proxeny decrees is attested at Delphi up until the end of the second century вСE. After this time the entire honorific culture of Delphi was transformed due to both external (the advent of Rome) and internal (oligarchisation) factors.

When we contrast the distribution of proxenoi from the third century вСЕ (Map 4) with the second century вСе (Map 5), the conclusion is that the Delphic network had changed. The core of the network is similar to those from the previous eras, as the majority of dots is located in central Greece, Attica and the Peloponnese. ${ }^{77}$ There is also still a significant concentration of proxenoi on the west coast of Asia Minor. ${ }^{78}$ However, in the latter period some regions are missing or are represented by a much smaller number of proxenoi. In contrast, a reduced number of proxeno $i$ is recorded to the north, where they are limited to a few Macedonian cities (Thessaloniki, ${ }^{79}$ Kassandreia $^{80}$ and Pella ${ }^{81}$ ) and are almost totally absent in the previously widely attested areas of Thrace and the Propontis region. The available epigraphic material also reveals a much smaller number of proxenoi from the south than in previous eras, with a lack of proxenoi from many of the islands, especially Crete, being particularly noticeable.

Surprisingly, the distribution of Delphic proxenoi in the second century ВСE extends over a wider range than in the fourth or even the third century BCE:

77 The proxenoi from central Greece: e.g. $F d D$ 1.151-1.153 (Naupaktos, west Lokris); $F d D$ 1.26o (Hypata, Dolopia); $F d D$ 1.28o (Tanagra, Boeotia); $F d D 1.354$ and $F d D 1.365$ (Thebes, Boeotia); $F d D$ 3.118 (Kierion, Thessaly); FdD 4.49-5o (Larisa, Thessaly); FdD 4.172 (Elateia, Phokis); Klio 18.1923.278.207 (Teithronion, Phokis). From Athens: FdD 1.228, FdD 2.33, FdD 2.49, $F d D$ 2.89, $F d D$ 2.91; $S y l l^{3} 711 \mathrm{~K}$. From the Peloponnese: $F d D 1.49$ (Aigeira, Achaia); $F d D$ 1.455 (Messenia); $F d D$ 3.119 (Karyneia, on the border between Achaia and Arkadia); $F d D$ 3.120 (Megalopolis, Arkadia); $F d D 3.125$ and 3.126 (Aigys, Lakonia).

$78 \quad F d D$ 1.454, FdD 1.273; Syll ${ }^{3} 585 ;$ SGDI 2644.

$79 \quad F d D$ 1.577.

$80 \quad S y l l^{3} 585$.

$81 \quad S y l l^{3} 5^{85}$. 


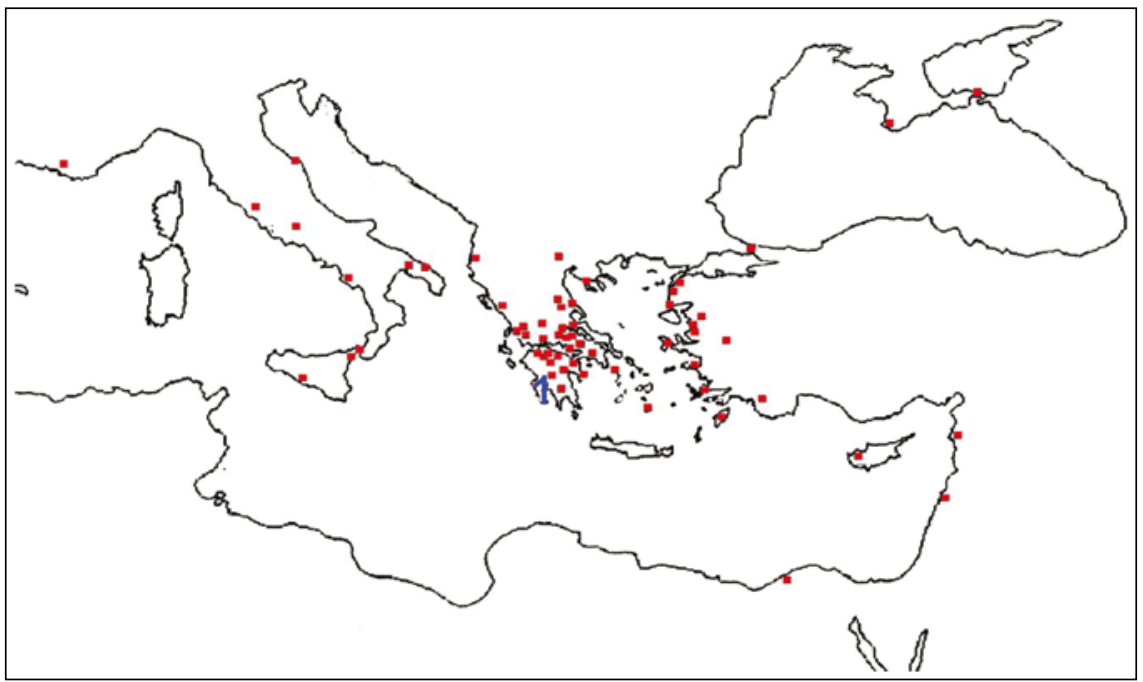

MAP 5 The second century BCE network of Delphic proxenia Note: 1 - Messenia.

this is due to the proxenoi from central Italy (Ankon, ${ }^{82} \mathrm{Arpi}^{83}$ and Rome ${ }^{84}$ ) and Sicily (Rhegion, ${ }^{85}$ Tauromenion ${ }^{86}$ and Akragas ${ }^{87}$ ) who are counted alongside four proxenoi from Massalia ${ }^{88}$ (the most westward attested proxenoi of Delphi) and Pantikapaion ${ }^{89}$ (the most eastward example).

This geographical diversity of the Delphic network in the second century BCE can be explained by a preserved chronological list of Delphic proxenoi appointed over twenty-two years from 197/6 to 175/4 BCE..$^{90}$ This gives us 121 individual proxeno $i$ with at least 54 different ethnics. Among them there are many previously unattested distant cities, such as Massalia, Arpi, Akragas, Elas, Pella, Thera, Pantikapaion and Tlos. Without the list, the horizon of the second century BCE Delphic proxeny network would be much more local. To avoid

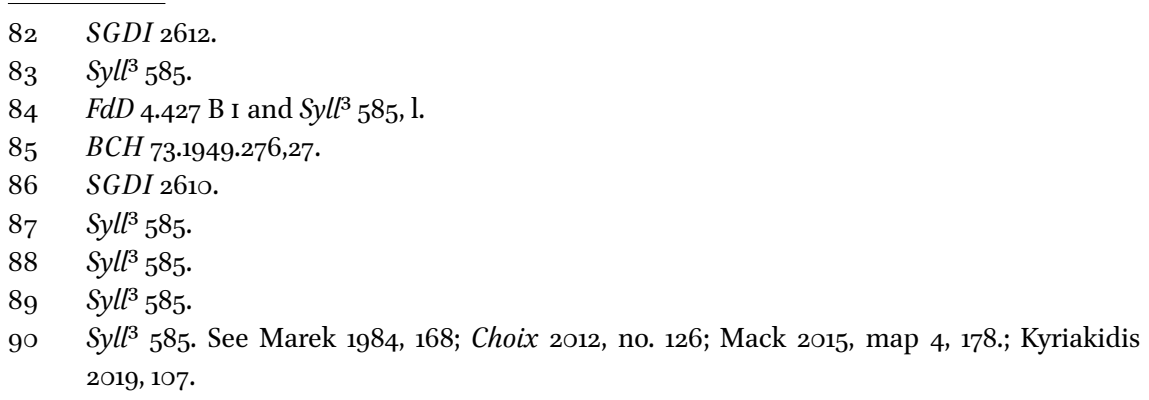




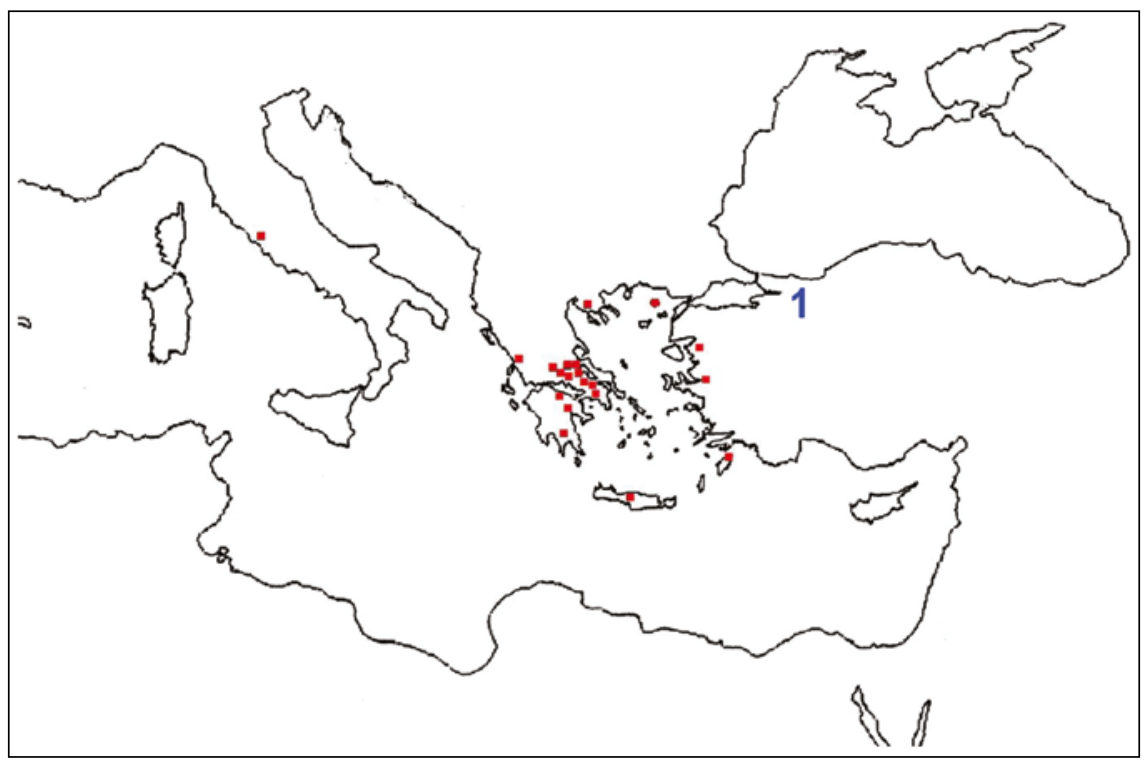

MAP 6 The first century BCE network of Delphic proxenia Note: 1 - Bithynia.

repetition, the reasoning behind the appointment of proxenoi from particular poleis and regions will be discussed in the next chapter.

During the first century вСE the Delphic network of proxenoi underwent significant regionalisation in comparison with previous eras (Map 6). By this time Delphi no longer looks north, west or east; or, to put the point more accurately, these regions no longer look at Delphi, as all eyes have now turned to Rome, including Delphi's own. Delphic proxenoi of this time were mainly inhabitants of central Greece: the evidence reveals at least five Boeotians, ${ }^{91}$ six Athenians, ${ }^{92}$ a group of the artists of Dionysus, ${ }^{93}$ a number of citizens from the local Phokian poleis, ${ }^{94}$ and finally, a few Dolopians..$^{95}$ No longer are the citizens of the Greek islands attested as proxenoi of Delphi, with the sole exception coming in the form of two artists from Eleutherna on Crete who received Delphic privileges. ${ }^{96}$ The picture that emerges is of a local sanctuary

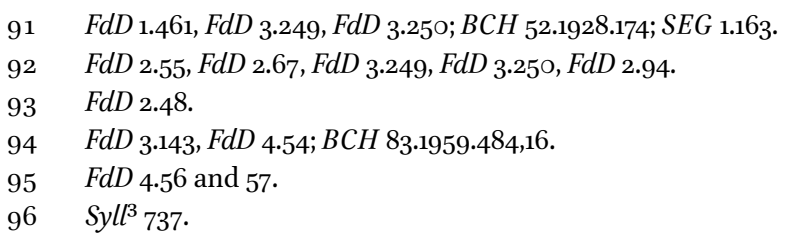




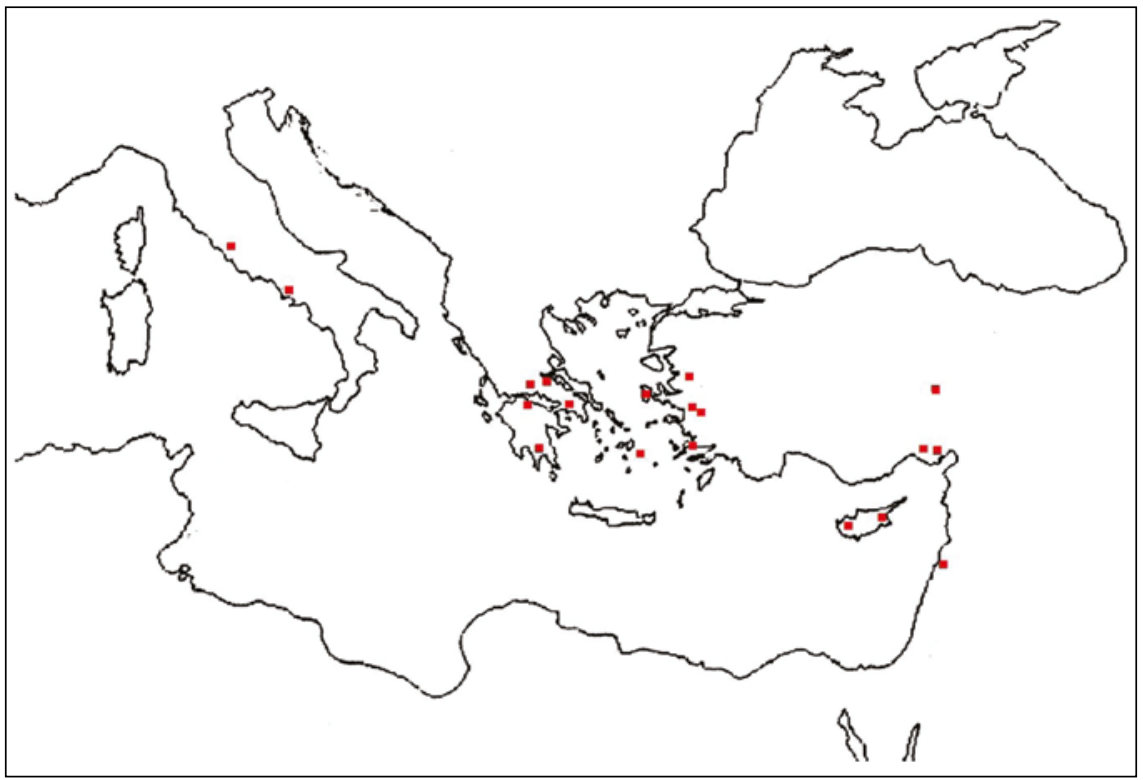

MAP 7 The network of Delphic proxenia in the imperial period

that mainly attracted artists from the neighbouring poleis. ${ }^{97}$ Delphi's contacts reach as far as Rome to the west ${ }^{98}$ and Bithynia to the east ${ }^{99}$ but without many dots in-between.

The picture that emerges from the last map (Map 7) is of a city with a very poor network of proxenia in comparison with previous centuries. It must be remembered, however, that in most of the Greek poleis the practice of bestowing proxenia was practically dead during this period and for this reason the Delphic record in particular is worth commenting upon. ${ }^{100}$ The first important feature of the proxeny network of Roman Delphi is that fourteen out of eighteen

97 Among the artists granted Delphic proxenia in the first century вСЕ one should mention a harpist from Thebes named Polygnota who came to Delphi to participate in the Pythian Games; the festival was, however, cancelled due to the ongoing war between Sulla and Mithridates ( $F d D$ 3.249, 86 BCE). Polygnota arrived with her cousin, Lykios son of Dorotheos, who was also honoured by the Delphic polis ( $F d D$ 3.25o). See Bélis 1999, 53-55; Chaniotis 2009, 87-91; Choix 2012, nos. 208-209.

$98 \quad F d D$ 4.44-46, FdD 4.438; SGDI 2688; Syll 77 .

$99 \quad F d D 4.77$.

100 Mack 2015, 233-243. Proxenia was occasionally granted in the imperial period by Gytheion in the Peloponnese ( $I G \mathrm{~V}, 1$ 1523, second century CE?); Methana on Peloponnese (IG IV 853, first century CE?); Samothrake (I.Kaunos 28, first century CE?); Byzantion (I.Kaunos 79, imp.). There are many examples from Chersonesos Pontica, e.g. SEG 48 999; IOSPE $\mathrm{I}^{2} 697$, IOSPE $\mathrm{I}^{2} 364$, IOSPE $\mathrm{I}^{2} 359$. 
proxeny grants are preceded by citizenship. ${ }^{101}$ The honorific title of proxenos therefore acted as an extra item which was issued together with politeia probably only due to its historical importance. ${ }^{102}$ Another feature is that at least nine out of eighteen Delphic proxeny decrees were voted on for different types of artists, philosophers and musicians. Most of them came from the distant regions of Mazaka in Kappadokia, ${ }^{103}$ Rhosos in Syria, ${ }^{104}$ Tralles Caesarea in Karia, ${ }^{105}$ Berytos in Phoenicia ${ }^{106}$ and even the previously unattested Puteoli. ${ }^{107}$ This tendency of honouring foreign artists marks the continuation of a trend from the first century вСE, when among the recipients of Delphic proxenia we also find many 'men of letters.'.108

Mack claims that proxenia as bestowed on philosophers and musicians was a reward for their activities at Delphi and that it served only as an honorific title without any further duties. ${ }^{109}$ Pace Mack, Puech raises the possibility that these later recipients may in fact really act as Delphic proxenoi in the old sense. ${ }^{110}$ However, it seems doubtful that during the imperial period the citizens of Delphi would need proxenoi from Kappadokia, Syria or Kilikia, especially since Delphic relations with these regions are rarely attested before. Moreover, in the imperial period not only does the title of proxenos testify to the gradual degradation of its value, but it also seems that the system of patronage shared the same fate in Greece. Eilers notices that Greek cities regularly adopted patrons throughout the late Republic and well into Augustan times. At some point during Augustus' reign this began to change, and the number of patrons was greatly reduced. ${ }^{111}$ The title of patronus became more local and increasingly honorific; Nicols proves, however, that the institution of the civic

\footnotetext{
$101 F d D$ 4.443, FdD 4.59, FdD 3.231, FdD 4.100, FdD 4.101, FdD 4.113, FdD 4.116, FdD 4.34, FdD 4.35, $F d D$ 4.91, $F d D$ 4.94, $F d D$ 3.298, $F d D$ 4.444, $F d D 4.107$ (the date of the last decree is uncertain, but the order of privileges mentioned within the document may suggest the imperial period).

102 Mack 2015, 244.

$103 F d D$ 4.59. See van Liefferinge 2000, 149-164.

104 FdD 4.113. See Choix 2012, no. 289.

105 FdD 4.116. See Choix 2012, no. 282.

106 FdD 4.91. See Choix 2012, no. 293.

$107 F d D$ 4.34. See Choix 2012, no. 287. See also the philosopher from Halikarnassos ( $F d D$ 4.107, van Liefferinge 2000, 149-164); choraules from Magnesia (FdD 3.129, Choix 2012, no. 283); the group of Platonic philosophers from Paphos (Cyprus), Athens and Mallos (Kilikia) (FdD 4.94, Choix 2012, no. 294 and DPA II 1994, no. B2, 47-48 and no. C188, 459); and a physician from Amorgos ( $F d D$ 3.298, Samama 2003, no. 65).

108 The term 'men of letters' is taken over from Bouvier (1985, 119-135).

109 Mack 2015, 244.

110 Puech 2012, 195-212.

111 Nicols 199o, 81-100; Eilers 2002, 161.
} 
patronus, although changed, remained important for the socio-political life of the empire. ${ }^{12}$ There are thus some similarities between the Roman patronage system and Greek proxenia, ${ }^{113}$ since both were important and desired to begin with; after Augustus, however, they simply became honorific titles without their former esteem. For various reason the citizens of Greece no longer needed Roman patrons in the old sense, just like they did not need the old type of proxenoi.

\subsection{The Citizens of Delphi as Proxenoi of Other Cities and States}

Interestingly, citizens of Delphi attested as proxenoi of other cities and states are only cursorily treated in scholarship. Discussion of this matter is worthwhile, however, because it reveals another aspect of Delphic relations with other members of the Greek world and the place that local individuals had within the Delphic honorific system. This will also enable us to examine the mutual interactions between Delphi and other communities that were facilitated by both the granting of proxeny and through acting as proxenoi of other communities (Maps 8-9). Moreover, due to the lack of Delphic epitaphs and the small number of decrees dedicated to Delphi's own inhabitants, foreign grants of proxenia for citizens of Delphi at least to some extent fill in the gaps that remain regarding the activity of the local citizenry in both an internal and external context.

Close analysis of Map 9, together with Appendix 2 that both identify Delphic citizens who performed as proxenoi of other cities reveals that Athens was the first polis to have appointed a Delphian as a proxenos (Appendix 2, no. 11). Gerolymatos claims that Athenian grants of proxenia from the fifth century BCE probably originate from a political context. ${ }^{114}$ Since the grant was made sometime between $45^{\circ}$ and 420 BCE we may assume that it concerns events which happened before or during the Peloponnesian War and concerns the Athenian rivalry with Sparta which either preceded the war or took place during the conflict. This rivalry is particularly visible in Delphi in the form of honorific portraits and dedications that were set up by both sides in order to demonstrate their supremacy over the Delphic temenos and the whole of Greece. ${ }^{115}$ The honorific title of an Athenian proxenos granted to a Delphic citizen might be a part of this rivalry. Surprisingly, citizens of Delphi

\footnotetext{
112 Nicols 2014, 16o.

113 For similarities and dissimilarities of proxenia and patronage, see Payne 1984, 84-86.

114 Gerolymatos 1986. See also Wallace 1970, 189-208.

115 Grzesik 2018a, 26-29.
} 


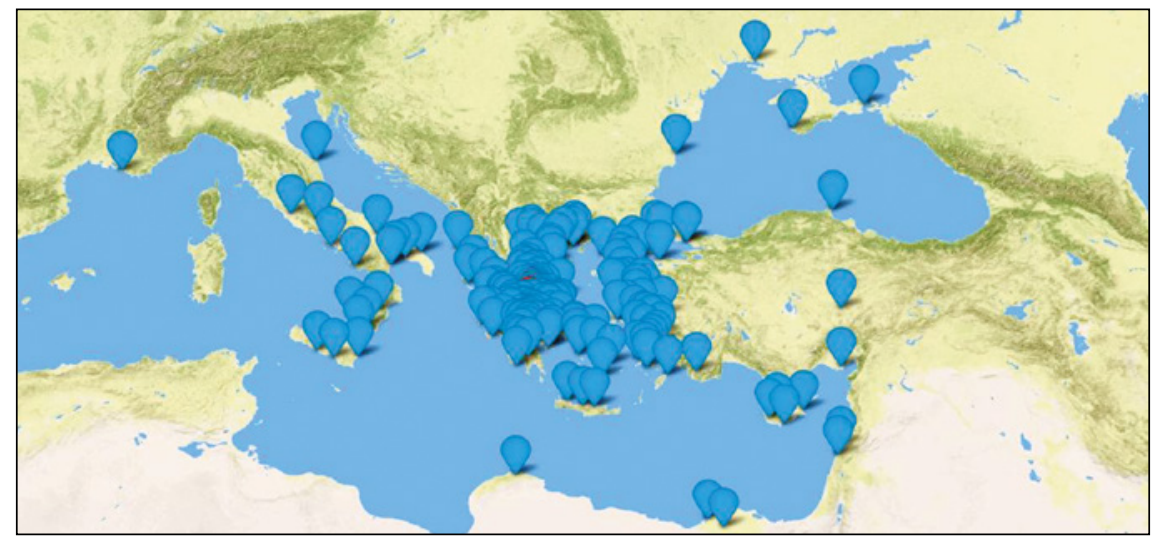

MAP 8 The range of the Delphic proxeny network from the fourth century вCE to the late second century CE (following Mack)

Note: http://proxenies.csad.ox.ac.uk/representatives/search?granting_authority _id=6o\&granting_authority_nature_id=\&region_id=\&proxenos_city_id=\&nature _of_community_id=\&nature_of_other_political_community_id=\&communal _region_id $=\&$ DateRange $=\&$ Person $=\&$ other_description_id $=\&$ Honours $=\&$ reference _type_id=\&epigraphic_medium_id=; (accessed 27 May 2019).

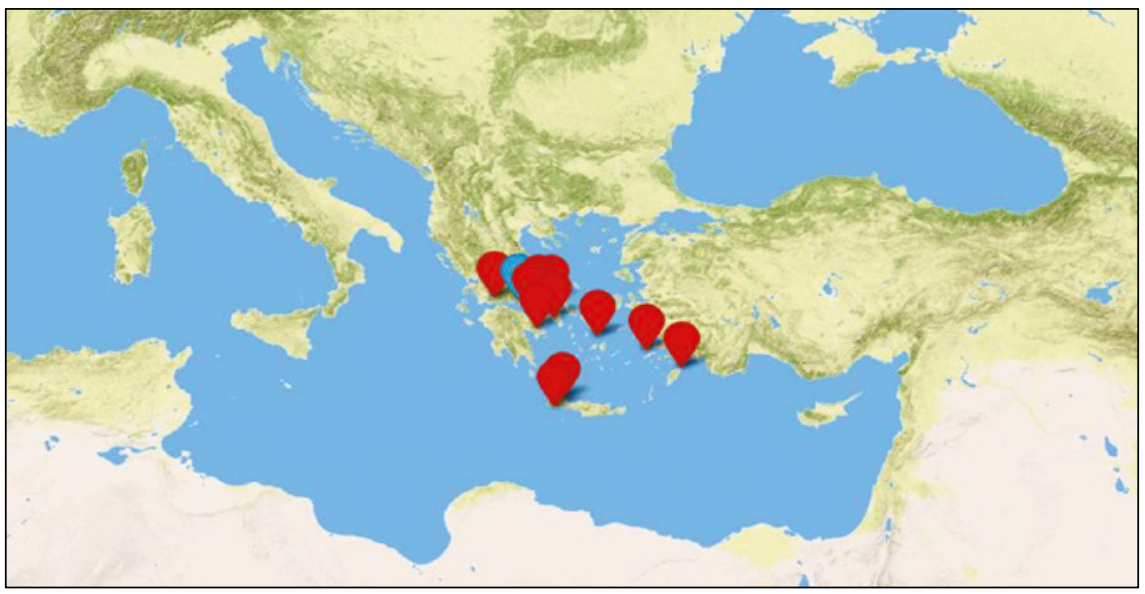

MAP 9 The citizens of Delphi attested as proxenoi of other cities and states (following Mack) Note: http://proxenies.csad.ox.ac.uk/representatives/search?granting_authority _id=\&granting_authority_nature_id=\&region_id=\&proxenos_city_id=6o\&nature _of_community_id=\&nature_of_other_political_community_id=\&communal _region_id $=\&$ DateRange $=\&$ Person $=\&$ other_description_id $=\&$ Honours $=\&$ reference _type_id=\&epigraphic_medium_id=; (accessed 27 May 2019). 
were appointed as proxenoi of Athens on only two occasions, once in the late fifth and once in the early fourth century вСЕ (Appendix 2, nos. 10-11), while Delphi made Athenians its proxenoi at least 62 times. One likely explanation for this is that in classical and early Hellenistic times Delphic ties with Athens were particularly strong as Delphic citizens appear as foreign residents of Athens exclusively in the fourth century вСЕ. ${ }^{116}$ The Aetolian domination over the Delphic territory weakened the relationship which had existed earlier between Delphi and Athens. This is evidenced by the fact that, whereas theoriai are attested as sent from Athens to Delphi in the classical period, there is a long break between this and the following theoria in 138/137. Theoriai were then sent again in $128 / 127,106 / 5$ and $98 / 7 .{ }^{117}$

A second observation worth noting is that in the fourth century BCE there are only four grants of proxenia made for Delphians. Besides the one from Athens (Appendix 2, no. 10), three documents reveal Delphians as proxenoi of Kalymnos (Appendix 2, nos. 15-17). Unfortunately, not much can be said about Delphic contacts with Kalymnos except the fact that two Delphic proxenoi of Kalymnos were related, as Alexidikos was the father of Parmeniskos. The trend of granting proxenia to father and son(s) recurs several times throughout the following centuries (Appendix 2, nos. 6-8, 11(?), 15 and 17). It is therefore debatable whether Greek honours were in fact inherited by descendants or whether a new decree was required in order to renew privileges. ${ }^{118}$

The following century (third century ВСЕ) witnessed the largest number of Delphians appointed as proxenoi of other cities (Appendix 2, nos. 1-4, 12-14 and 19). However, the proxeny decrees reveal purely local affairs. This is due to the fact that the Aetolian League (three grants), Epidauros (two grants), Delos (one grant), Kydonia on Crete (one grant), and Chorsiai in Boeotia (one grant) all appointed a large proportion of proxenoi from Delphi. When looking at Map 9 one realizes that citizens of Delphi generally did not act as proxenoi of distant regions, but rather focussed on neighbouring communities and the Aegean islands. It is also worth mentioning Archagoras, a proxenos of Kydonia on Crete (no. 19), who was granted the right to lease land and property along with proxenia, as he was involved with the distribution or production of Cretan wine. ${ }^{119}$

\footnotetext{
116 Osborne and Byrne 1996, 63 .

$117 F d D$ 2.2-67. See Colin 19o9-1913, 11-70; Sifakis 1967, 86.

118 Mack 2015, 30-32 and 164.

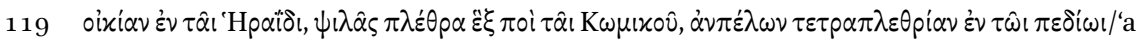
house in Herais, six plethra of arable land near the Komikos, four plethra of vineyard in the plain' (IC II 10, 1 l.16-18). See Marangou-Lerat 1995, T. 12. On the term $x \dot{\omega} \mu \eta$, see Perlman 1996, 243-244.
} 
Another observation concerns the proxenoi of Delos. The citizens of Delos created an impressive proxeny network with at least 239 records. ${ }^{120}$ Only on one occasion did an inhabitant of Delphi act as a Delian proxenos (Appendix 2, no. 14) while, surprisingly, no private individual from Delos has ever been appointed as a Delphic proxenos. This suggests that contact between the two main Greek sanctuaries of Apollo was very limited. Was this due to an atmosphere of competition for the attention of external audiences, or rather a rivalry over the status of being the primary Greek sanctuary during the Hellenistic era?

Among the twenty known citizens of Delphi that took upon the duties of proxenoi of other poleis one character particularly stands out in the sample. The proxeny grant issued by Rhodes to Praxias, son of Eudokos (Appendix 2, no. 18) is worth commenting upon as Praxias came from a prominent Delphic family whose members are known from many testimonies. ${ }^{121}$ For example, it is known that Praxias performed as an ambassador sent to Eumenes II, ${ }^{122}$ Attalos II ${ }^{123}$ and to Rhodes, while for the latter mission he was granted Rhodian proxenia. ${ }^{124} \mathrm{He}$ is attested as a Delphic archon, bouleutes, and at the end of his career as a priest of Apollo. ${ }^{125}$ Praxia's wife, Praxo, was one of the wealthiest and most influential women in Delphi. Livy states that she was a friend of king Perseus and that she allowed the assassins who were hired by Perseus to kill Eumenes stay at her home at Delphi. ${ }^{26}$ According to Daux, Thrasykles, brother of Praxias, was one of the ambassadors sent to Rome who was murdered during his return in 189 BCE. ${ }^{127}$ Also relevant to this study is the fact that Praxias received the title of proxenos for performing as an ambassador. It seems that acting as a Delphic or Amphictyonic envoy (ambassador or theoros, Appendix 2, nos. 5(?), 13 and 18) was the easiest way for Delphians to earn the title of proxenoi from foreign states. In this connection, Diodoros, son of Dorotheos (Appendix 2, no. 5) became a proxenos of Thespiai, but there is a series of mostly fragmentary documents which reveal that he was also honoured by other cities and koina, most probably because of his service as a Delphic public official. ${ }^{128}$

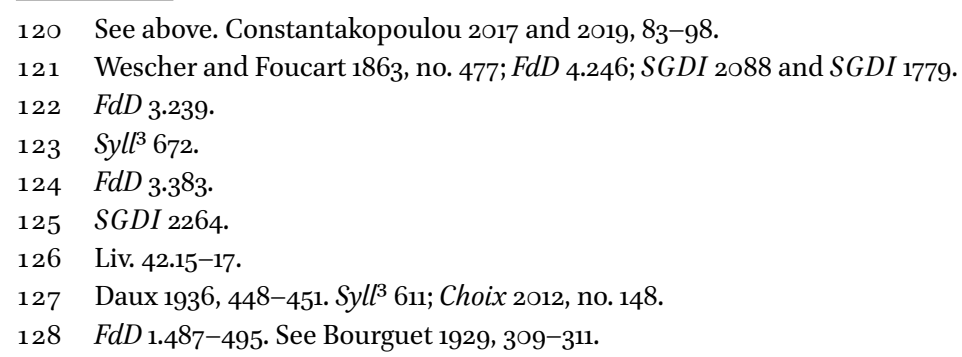


This last observation helps to reveal the types of links which Delphi managed to create through its proxeny network. Appendix 2 shows that Delphi built bilateral relations only with its closest neighbours (the Aetolian League, Thespiai, Chalkis, Athens, Epidauros) and with three Aegean islands (Kalymnos, Rhodes and Crete). Moreover, most of these links were established for a short period of time. Altogether it indicates that the Delphic proxeny network more often worked as a one-way system, not a reciprocal process, as was typical for proxenia or theorodokia. ${ }^{129}$

To conclude, the comparison of the range of Delphic proxenoi (Map 8) with citizens of Delphi who were selected as proxenoi of other communities (Map 9) demonstrates that proxenia was bestowed much more often than it was received by Delphians. The ratio is approximately 700 to 20 . Moreover, the range of the Delphic proxenoi is global while the inhabitants of Delphi acting as proxenoi created rather regional interactions. All this strengthens the notion that the granting of Delphic proxeny served as a proleptic honour whose task was to encourage foreign benefactors to make the effort to gain the honorific title of the Delphic proxenos through their benefactions. Through proxenia the citizens of Delphi managed to create a wide network of honorands and to maintain international relationships with both neighbouring and distant communities.

\subsection{Conclusion}

The Delphic proxeny network was most probably based on political, economic, and cultural interactions of which we can only obtain a limited sense from our sources. Throughout the centuries it allowed Delphi to assert itself as the centre of the Greek world, above all in the third and second centuries BCE, when the range of the Delphic network was global. With the advent of Rome, though, the entire Greek honorific culture changed as all eyes now turned to the west. The mutual interactions of poleis fell into decline. Not only did the proxeny networks thereafter shrink, but also other popular forms of Greek integrations such as interstate arbitration, the recognition of asylia, the dispatch of theoroi, or the practice of asking for judges from other cities were no longer attested in Greece by the time of Augustus.

The comparison of the scale of networks of proxenoi from different poleis reveals that the range of a network and its reach were not necessarily correlated to the size of the city, but rather reflects the horizons of the community

129 Rutherford 2007, 24. 
and interests of its citizens. The range of the Delphic proxeny network was similar to the networks created by the League of the Aetolians during its heyday in the third and second centuries BCE, the Delian network, and, to some extent, the Oropean network. ${ }^{130}$ Mack at the end of his book presents a map that reveals the range of the network of 240 different poleis. ${ }^{131}$ This collective network is denser than that of Delphi, but it is significant that the most eastward, northward, southward and westward examples are all attributed to Delphi.

Following Granovetter's ideas used in Social Network Analysis, Mack further claims that proxeny networks should be interpreted as a 'weak tie' in networks, since, in contrast to 'strong ties', proxenia does not represent emotional or intimate contacts between the actors involved. ${ }^{132}$ However, I argue that some of the Delphic ties which are maintained over three or more centuries, in contrast to those links attested only for one or two hundred years, can be interpreted as 'strong ties'. Without a doubt the Delphic relations with Athens were particularly strong as they are attested from the fourth century вСЕ (or even from the fifth century if we take into account the Delphic proxenoi of Athens) without any break-up to the imperial era. Moreover, they were based on different grounds and levels. ${ }^{133}$ Delphic relations with Boeotia and the Peloponnese can also be interpreted as 'strong ties'.

I also disagree with Mack's approach that, at least in the case of Delphi, the preserved proxeny lists or catalogues of proxenoi represent more valuable material for revealing the network of proxenoi than honorific decrees. ${ }^{134}$ The lists of proxenoi are better for comparisons due to the huge disproportion between the numbers of preserved proxeny decrees from different poleis; however, they are concerned with a very limited time span and due to this many trends can be overlooked. My approach allows the dynamics behind the process of creating the Delphic proxeny network throughout the centuries to be examined, as well as the identification of any factors that directly or indirectly impacted it. Additionally, presenting the research in map form both reveals the number of proxenoi appointed in each period and shows the directions to which Delphi looked in the Hellenistic and Roman times, while also highlighting any repetitive trends within Delphic honorific culture. The same cannot be said about Mack's approach, which provides a rather static overview.

130 The League of the Aetolians proxeny network (Mack 2015, 291, map 7); the Delian honorific network (Constantakopoulou 2017, 160, fig. 4.1.); the Oropean proxeny network (Fossey 2014, 15, fig. 7).

131 Mack 2015, 344, map 17. Compare Mack 2015, 178, map 4.

132 Mack 2015, 149-15o. Granovetter 1983, 201-233.

133 See Chapter 4.1.

134 Mack 2015, 152-163. 